\title{
Identification of Species Composition of Fish in the Zarivar Lake (Kurdistan Province of Iran)
}

\author{
Mansoureh Gholami ${ }^{*}$, Maryam Shapoori² \\ ${ }^{1}$ Department of Natural Resources, Sanandaj Branch, Islamic Azad University, Sanandaj, Iran \\ ${ }^{2}$ Department of Natural Resources, Savadkooh Branch, Islamic Azad University, Savadkooh, Iran \\ Email: ^gholami62@yahoo.com
}

How to cite this paper: Gholami, M. and Shapoori, M. (2017) Identification of Species Composition of Fish in the Zarivar Lake (Kurdistan Province of Iran). Open Journal of Marine Science, 7, 205-210. http://dx.doi.org/10.4236/ojms.2017.71015

Received: November 15, 2016

Accepted: January 22, 2017

Published: January 25, 2017

Copyright $\odot 2017$ by authors and Scientific Research Publishing Inc. This work is licensed under the Creative Commons Attribution International License (CC BY 4.0).

http://creativecommons.org/licenses/by/4.0/

\begin{abstract}
Zarivar Lake is a small, freshwater body in the far west of Iran, situated in the north Kurdistan Province close to the city of Marivan, with an area of about 750 ha and average water depth of 4 - 5 meters. During a survey of Zarivar Lake from 2010 to 2011, some specimens were obtained by seasonal sampling in 5 stations. They were used for gill net sampling in the lake. Due to the results, 6 species from 2 families in Zarivar Lake were identified. Most of the fish species belonged to Cyprinidae family. Totally, 6 species (Cyprinus carpio, Ctenopharyngodon idella, Capoeta damascina, Chalcalburnus sp., Hypophthalmichthys molitrix and Gambosia affinis) were identified from Cyprinidae and Poeciliidae families.
\end{abstract}

\section{Keywords}

Zarivar Lake, Cyprinidae, Abundance, Species Compositions

\section{Introduction}

This study was conducted in the Zarivar Lake in 2010. Zarivar Lake is a small, freshwater body in the North West of Marivan city. The continued existence of the lake is mostly dependent upon the quantity of water coming up through natural springs on the lake bottom. The annual average temperature of the water ranges from $0.5^{\circ} \mathrm{C}$ to $27.3^{\circ} \mathrm{C}$. The volume of Zarivar Lake has been calculated to range from about 22 to 47 million cubic meters of water [1].

This lake has emerged due to severe erosion of geological phenomena of region and emerging of fault; and because of the weak layers and settling in this area, bed gradually comes down and earth drainage and water collecting are provided. Totally, Marivan is located in the northern part of Zagros' folding, tectonically is in an active area and its folding is related to the mid-Tertiary period of geology. Zarivar as an aquatic ecosystem from the perspective of the environment is of importance and values of passion. Zarivar 
Lake is the only natural lake in the heart of the Zagros Mountains where surrounded by mountains with forests from the front of the west, east and north. The bar on the lake surrounded by dense aquatic plants hinders human user's progress to the privacy of lake.

This lake is a genetic nature reserve for a variety of aquatic animals and waders, and the main water supplier source of it is the boiling Palm Springs, where is less affected by species transmitted from its basin. Zarivar is a wetland lake in one of the most important stops for migratory birds in winter and other passing migratory birds in the other seasons, and annually receives 6 thousand migratory aquatic birds. It is considered as the potential tourism base (especially Ecotourism) due to the natural landscape, having paved shores of the beach, having a wall of mountains covered with forests, fresh water with sufficient depth and ease of access. The lake as an aquatic habitat for fish breeding is eligible to completed capacity which according to them could have economic and recreational benefits in the region.

On the other hand, preparing plans to convert some villages to the city, the entrance of the lake outlet area construction, the development of animal husbandry and agricultural activities, tourist facilities and many abnormal interactions with no evaluation and capacity assessment have led to the crisis of the lake. And creatures of lake are at serious risk; the lakes receiving sewage and agricultural wastes of villages contaminated with pesticides and organic materials reduced self-purification capacity and capacity utilization of the lake. Lake is water body which is home to many aquatic animals and plants. The creatures available in every area including fish represent the ecological conditions of the environment of region. Certain species of fish are able to live in every aquatic ecosystem. Freshwater amount although forms much less than one percent of the total amount of water body, $41 \%$ of the world's fish belongs to freshwater and according to Nelson, all fish species in the world are about 28,500 species [2]. Of these at least 10,000 species belong to freshwater. Iran is located in an important geographical animal area and therefore has a diverse and interesting fish fauna. Freshwater fish fauna falls in the 15 orders, 24 families, and 65 genera and has at least 155 species.

\section{Materials and Methods}

The lake is situated in the Iranian province of Kurdistan west of Marivan and has a length of $5 \mathrm{~km}$ and a maximum width of $1.6 \mathrm{~km}$. The lake's water is fresh and has a maximum depth of 6 meters (Figure 1). Zarivar, such a dreamy lake, is fed by no river and its water is provided only by the snow melted in the surrounding mountains (Figure 2).

Fish samples were acquired, using a gillnet, bag net and hook by local fishermen from Zarivar Lake during Winter 2010 and the Spring, Summer and Autumn of 2011 and transported live to the laboratory (Figure 3).

Preferred stations for sampling and testing were based on studies and research objectives were selected using GPS. To select the stations such as size, natural and artificial factors affecting the condition of the lake such as villages, towns and human traffic, the distance from each station to these factors, Significant changes in lake conditions and physical, chemical-biological conditions so that comparisons can be made between 


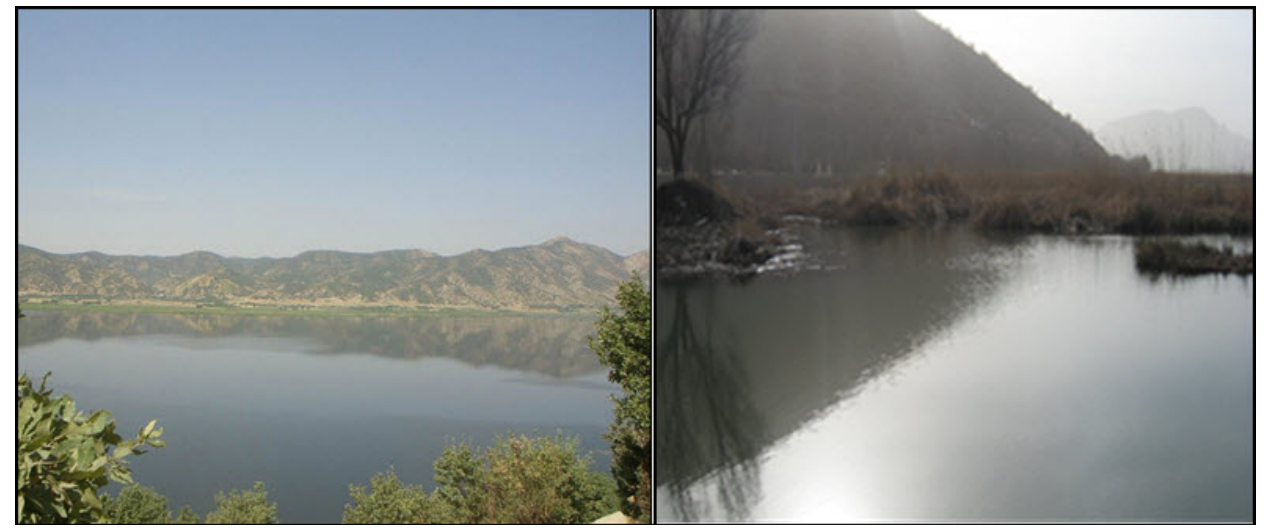

Figure 1. View of Zarivar Lake.

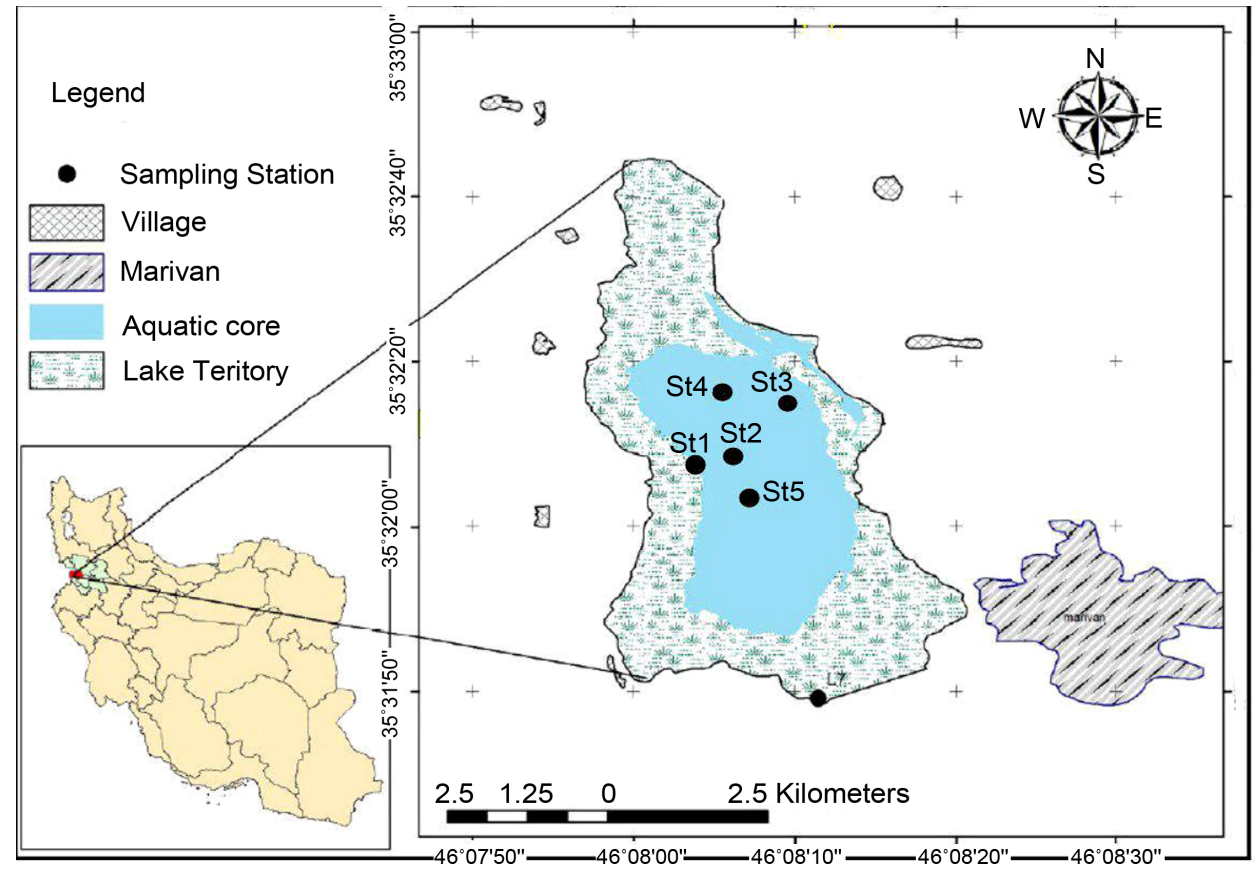

Figure 2. Map showing situation of the Zarivar Lake.

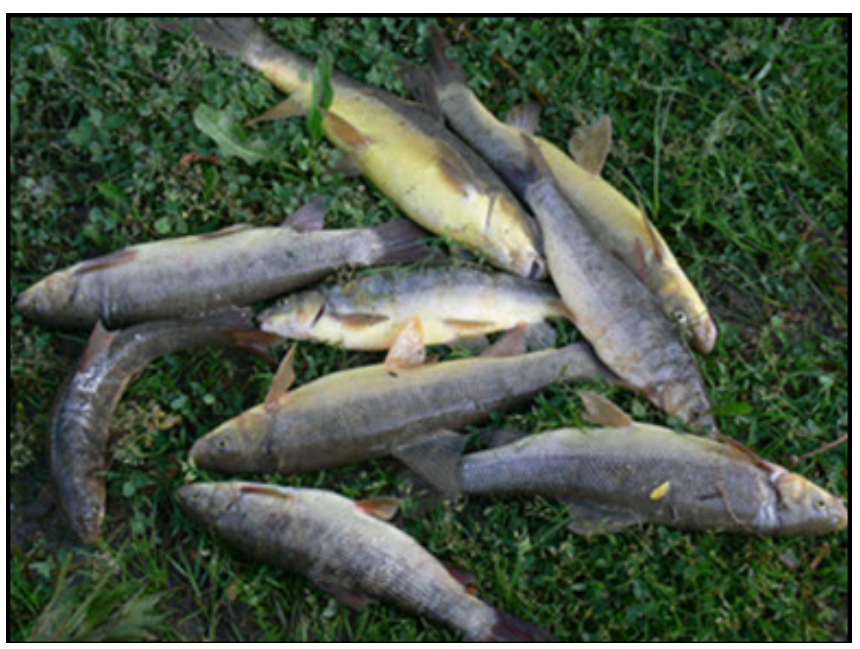

Figure 3. Catch of fishes by gill net. 
stations and access and a sampling from each site in all seasons was considered. Finally, 5 stations were chosen and determined (Table 1). This makes it possible to select the number of stations to determine the status of the lake as well as study the environmental impact.

The specimens were preserved in 5\% formalin and were transferred to the laboratory for further examinations. Fishes were identified based on morphologic and meristic characteristics. 4 morphometric characteristics were recorded for each specimen.

\section{Result and Discussion}

The obtained results show that this wetland is very talented in the field of ecotourism. Zarivar Lake is inland wetland according to mentioned classification. It is the only natural aquatic ecosystem in Kurdistan province in Iran. This lake has formed due to severe erosion of geological formations of the region [3].

The results showed that 6 fish species belonging to 2 families were recorded in the lake (Table 2).

Five of these species belonging to the family Cyprinidae were abundant in the Lake (Table 3).

Table 1. Summary information about the geographical coordinates of sampling stations.

\begin{tabular}{ccc}
\hline Station & $(\mathrm{N})$ & (E) \\
\hline Parallel Side (St1) & $35^{\circ} 32^{\prime} 01^{\prime \prime}$ & $46^{\circ} 08^{\prime} 00^{\prime \prime}$ \\
Center Of Lake (St2) & $35^{\circ} 32^{\prime} 1.6^{\prime \prime}$ & $46^{\circ} 08^{\prime} 02^{\prime \prime}$ \\
Small Of Lake (St3) & $35^{\circ} 32^{\prime} 02^{\prime \prime}$ & $46^{\circ} 08^{\prime} 01^{\prime \prime}$ \\
North Of Lake (St4) & $35^{\circ} 32^{\prime} 03^{\prime \prime}$ & $46^{\circ} 08^{\prime} 04^{\prime \prime}$ \\
South Of Lake (St5) & $35^{\circ} 32^{\prime} 2.5^{\prime \prime}$ & $46^{\circ} 08^{\prime} 06^{\prime \prime}$ \\
\hline
\end{tabular}

Table 2. Distribution of species in Zarivar Lake.

\begin{tabular}{ccccccc}
\hline & Scientific name & St1 & St2 & St3 & St4 & St5 \\
\hline 1 & Hypophthalmichthys molitrix & & $*$ & $*$ & $*$ & $*$ \\
2 & Cyprinus carpio & $*$ & $*$ & $*$ & $*$ & $*$ \\
3 & Ctenopharyngodon idella & $*$ & & $*$ & $*$ & $*$ \\
4 & Capoeta damascina & $*$ & $*$ & $*$ & $*$ & $*$ \\
5 & Gambosia affinis & $*$ & $*$ & & $*$ & $*$ \\
6 & Chalcalburnus sp. & $*$ & & & $*$ & $*$ \\
\hline
\end{tabular}

Table 3. List of identified fish species from Zarivar River.

\begin{tabular}{ccc}
\hline Scientific name & Family & English name \\
\hline Hypophthalmichthys molitrix & Cyprinidae & Silver carp \\
Cyprinus carpio & Cyprinidae & Common carp \\
Ctenopharyngodon idella & Cyprinidae & Grass carp \\
Capoeta damascina & Cyprinidae & Capoeta damascina \\
Gambosia affinis & Poeciliidae & Mosquitofish \\
Chalcalburnus $\mathrm{sp}$. & Cyprinidae & Alburnus \\
\hline
\end{tabular}


In Zarivar Lake, six species including Cyprinus carpio, Ctenopharyngodon idella, Capoeta damascina, Chalcalburnus sp., Hypophthalmichthys molitrix and Gambosia affinis as the most abundant species and they were found all over the lake (Table 4). This finding is in agreement with previous studies [4].

The result of the present study showed that the main species of the lake belong to the Cyprinidae family. The family Cyprinidae is the largest family of freshwater fishes and various members of this family are important as food fish, as an ornamental species for aquariums and also medical treatments [5].

Though several methods have been used for the identification of fish (Figure 4) but morphometric characters were considered as most primitive and authentic methods that had been mostly used in fish biology to calculate the discreteness and relations among various taxonomic categories [6].

Table 4. Morphometric features of fish species caught in Zarivar Lake (Mean \pm SD).

\begin{tabular}{cccccc}
\hline Species & N & TL & SL & HL & BD \\
\hline Hypophthalmichthys molitrix & 20 & $35 \pm 5$ & $30 \pm 3$ & $9 \pm 3$ & $10 \pm 2$ \\
Cyprinus carpio & 30 & $29.5 \pm 4$ & $25 \pm 5$ & $8 \pm 2$ & $8.5 \pm 3$ \\
Ctenopharyngodon idella & 16 & $38 \pm 6$ & $35 \pm 2$ & $10 \pm 3$ & $7 \pm 2$ \\
Capoeta damascina & 15 & $30 \pm 5$ & $24 \pm 4$ & $7 \pm 2$ & $5 \pm 2.2$ \\
Gambosia affinis & 18 & $8 \pm 3$ & $6 \pm 2$ & $1 \pm 0.5$ & $0.5 \pm 0.1$ \\
Chalcalburnus sp. & 5 & $20 \pm 3$ & $17 \pm 2$ & $7 \pm 2.3$ & $4 \pm 1$ \\
\hline
\end{tabular}

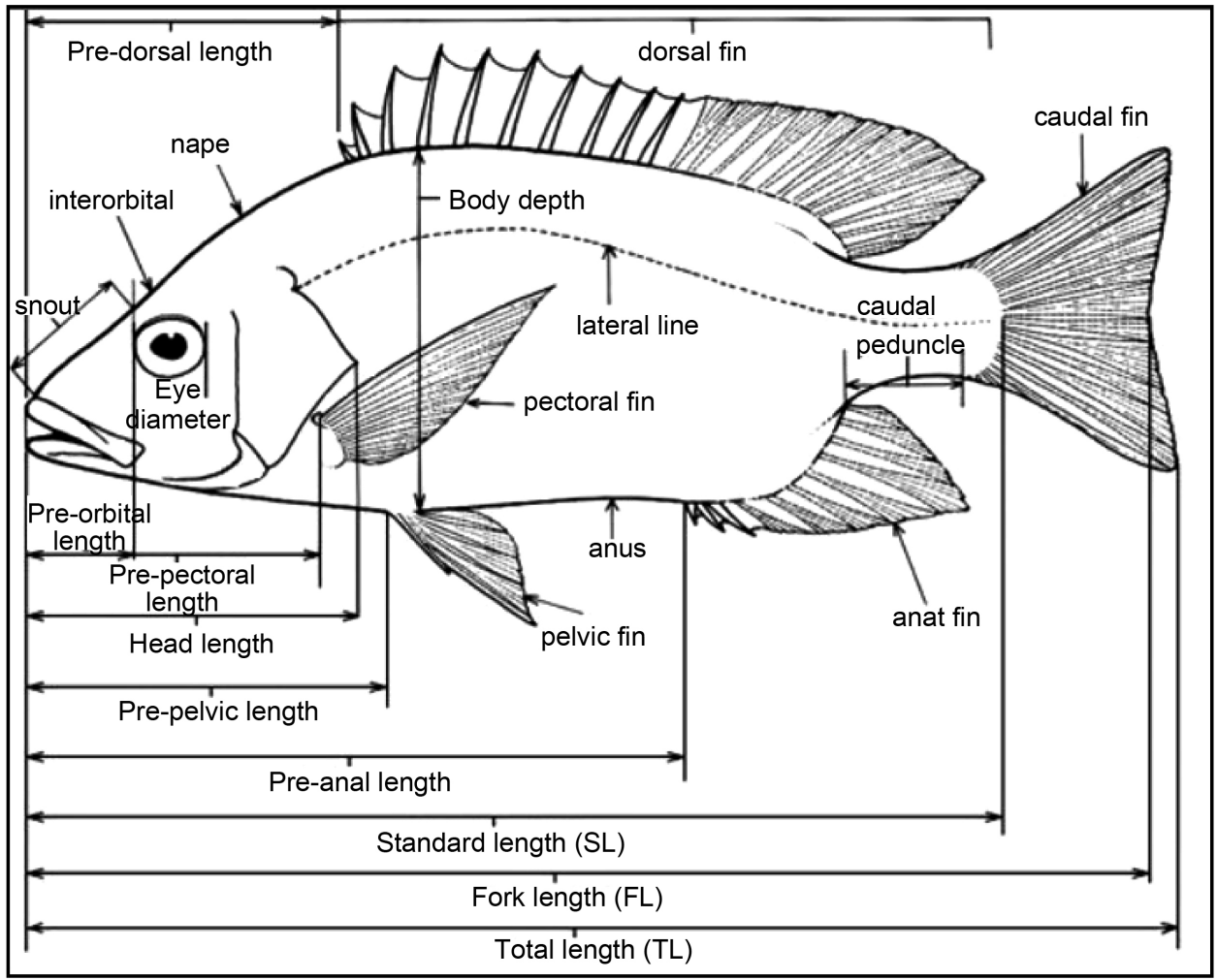

Figure 4. Measurements of the different morphometric and meristic parameters of fish. 
Our present study latter could be helpful to the students of fisheries, fisheries biologist and taxonomist for the correct identification and classification of Cyprinidae exists in various location of Iran.

\section{References}

[1] Jalali, B. and Barzegar, M. (2010) Fish Parasites in Zarivar Lake. Journal of Agricultural Science and Technology, 8, 47-58.

[2] Nelson, S.A. (1994) The Problem of Oil Pollution of the Sea. Advances in Marine Biology, 8, 215-306. https://doi.org/10.1016/S0065-2881(08)60493-9

[3] Reyahi-Khoram, M.A.H.D.I. and Hoshmand, K. (2012) Recognition of Physical and Biological Diversity of Zarivar Wetland in Kurdistan Province, Iran.

[4] Coad, B.W. (2013) Freshwater Fishes of Iran. http://www.briancoad.com

[5] Nelson, J. (2006) Fishes of the World. 4th Edition, John Wiley and Sons, $601 \mathrm{p}$.

[6] Rehman, F.U., Rehman, H.U., Aman, S., Aziz, S., Shabir, H., Majid, A. and Subhan, F. (2015) Morphometric and Meristic Analysis of Silver Carp (Hypophthalmichthys molitrix) from Tanda Dam, District Kohat, Pakistan.

Submit or recommend next manuscript to SCIRP and we will provide best service for you:

Accepting pre-submission inquiries through Email, Facebook, LinkedIn, Twitter, etc. A wide selection of journals (inclusive of 9 subjects, more than 200 journals)

Providing 24-hour high-quality service

User-friendly online submission system

Fair and swift peer-review system

Efficient typesetting and proofreading procedure

Display of the result of downloads and visits, as well as the number of cited articles

Maximum dissemination of your research work

Submit your manuscript at: http://papersubmission.scirp.org/

Or contact ojms@scirp.org 